\title{
Airport Water Consumption Footprinting
}

\author{
Merve Özlem Vurmaz, Hülya Boyacioglu* \\ Department of Environmental Engineering, Dokuz Eylul University, Tinaztepe Campus Buca 35390 Izmir, Turkey
}

Copyright $\subset 2018$ by authors, all rights reserved. Authors agree that this article remains permanently open access under the terms of the Creative Commons Attribution License 4.0 International License

\begin{abstract}
The study focused on water consumption footprinting and development of water efficiency plan for an airport located in Turkey. Airports are facilities having large water consumption, generally for non-potable purposes such as water cooling systems, fire control, cleaning and washing of vehicles, runways and aircrafts and also public uses (WC, food service). Research period covered 12 months and consumption data obtained from 116 water meters were evaluated for water footprinting. Along a year the airport served to about 12 million passengers and 81 thousand aircrafts. These passengers and aircrafts were served by various services by airport authorities. These services were linked by water consumption directly or indirectly. Study results showed that annual water consumption was about $436000 \mathrm{~m}^{3} /$ year. Irrigation, fire control system, cooling towers and terminal WC uses accounted high use with rate of $23 \%, 7 \%, 26 \%$ and $20 \%$. While water used for WC changed between about 6-8.5 L per pax, this value was between 1-1.5 L per pax for food consumption. Therefore passenger based uses fluctuated between 6.5-10 L per pax in the airport. Based on this analysis several methods were suggested to minimize water consumption. Among them "training and education of airport staff" was proposed as the most economical solution. Furthermore "improved water consumption monitoring" system could be suggested as applicable method considering economical and physical aspects and should gain priority. Then alternative measures could be chosen based on their economical and physical applicability.
\end{abstract}

Keywords Water Footprinting, Airport Water Footprint

\section{Introduction}

In parallel to population growth, high demand for water resulting droughts and unpredictable climatic patterns is becoming an alarming reality in many parts of the world. Increasing concerns regarding the consequences of climate change also emphasize the need for water resources management planning in order to guarantee that current and future demands [1].

Airport environments consume large amounts of water to maintain infrastructure and operations and, they rely on available potable and reclaimed water during construction and in daily operations, on the airfield and in the terminals. In most cases, large amounts of water are consumed at during the course of daily operations to support terminal operations such as restrooms, food service, and heating, ventilating, and air conditioning; airfield services such as deicing, construction, and firefighting; and maintenance activities such as vehicle cleaning and landscaping. This volume can also be met by alternative water sources (rainwater and treated effluent, e.g) [1,2].

Water-related issues are central to environmental programs at most airports. On a regular basis, airport staff make water management decisions to support permitting, regulatory compliance, development planning, infrastructure design, asset management, operations, and maintenance efforts [3].

Water efficiency efforts are becoming more critical because of the following reasons:

- climatic changes increasing the probability of variations in water availability from year to year

- $\quad$ cost of potable water

- the continued growth and expansion of urban centers threatening usable water amount [2].

The development of a water minimisation plan is an important element in the ongoing process of maximising the efficient use of water [4]. Implementing water efficiency practices can reduce costs and achieve a lower water footprint.

An airport's water footprint is the amount of fresh water which is used to provide services. Water consumption in the airports has been assessed and total consumption and index of L/passenger were calculated in annual reports of many airports in the world $[1,2]$.

Types of facilities, end uses in the airports and total water consumption per passenger at various airports are presented in Table 1 and 2.

Retrofit programs can greatly improve water efficiency at airports. Basic measures, such as water monitoring and water efficient amenities, are generally applicable to all 
airports while more complex and capital-intensive measures such as rainwater reuse and greywater recycling should be considered with detailed cost-benefit analysis in the context of the individual airport [5].

The study focused on water consumption footprinting and development of water efficiency plan for an airport located in Turkey.

Table 1. Types of facilities and end uses in the airports [2]

\begin{tabular}{|c|c|}
\hline Facility & Example of End Uses \\
\hline Terminals & $\begin{array}{c}\text { Toilets, urinals, bathroom and kitchen } \\
\text { faucets, dishwashers }\end{array}$ \\
\hline Office Buildings & $\begin{array}{c}\text { Window cleaning, Interior plant } \\
\text { watering, toilets, urinals, faucets }\end{array}$ \\
\hline Rental Car Center & $\begin{array}{c}\text { Fleet vehicle washing, outdoor } \\
\text { irrigation }\end{array}$ \\
\hline Ground Transportation & Vehicle washing \\
\hline Parking & Snow removal, street cleaning \\
\hline Fire and Police Stations & $\begin{array}{c}\text { Fleet vehicle washing, fire } \\
\text { suppression }\end{array}$ \\
\hline Hotels & $\begin{array}{c}\text { Toilets, showers, ice machines, } \\
\text { swimming pools, spas, laundry }\end{array}$ \\
\hline $\begin{array}{c}\text { Central Heating/Cooling } \\
\text { Plant }\end{array}$ & Boiler, cooling \\
\hline Maintenance and Services & $\begin{array}{c}\text { Runway rubber removal, employee } \\
\text { break rooms and restrooms }\end{array}$ \\
\hline Airlines/Aircrafts/Cargo & $\begin{array}{c}\text { Aircraft cleaning, on-board aircraft } \\
\text { water, de-icing }\end{array}$ \\
\hline
\end{tabular}

Table 2. Total water consumption per passenger at various airports in the World

\begin{tabular}{|c|c|c|}
\hline Airports & L/passenger & Reference \\
\hline Bristol Airport & 9.4 & {$[6]$} \\
\hline Amsterdam Airport & 13.3 & {$[7]$} \\
\hline Gatwick Airport & 17.08 & {$[8]$} \\
\hline Frankfurt Airport & 21.7 & {$[9]$} \\
\hline Porto Alegra Airport & 23 & {$[1]$} \\
\hline Salvador Airport & 23 & {$[1]$} \\
\hline Madrid Barajas & 23.09 & {$[10]$} \\
\hline Airport & 24 & {$[1]$} \\
\hline Recife Airport & 29 & {$[11]$} \\
\hline Heathrow Airport & 43 & {$[1]$} \\
\hline Lisbon Airport & & \\
\hline
\end{tabular}

\section{Study Area}

Study area comprises 4 terminals namely Domestic,
International, VIP and CIP. Monthly terminal passenger capacities and number of flights as of 2016-2017 are presented in Table 3. From March 2016 to February 2017 the airport served to about 12 million passengers and 81 thousand aircrafts. These passengers and aircrafts were served by various services by airport authorities. These services were linked by water consumption directly or indirectly.

The study aimed to design "Water Efficiency Plan" for the airport. In this scope firstly water consumption footprinting has been implemented. Then water efficiency plan was developed. The main target was to determine the most water consumed activities/facilities within the airport and propose efficiency plan to minimise these uses.

Overall objective was water saving considering climate change effects in near future in this region and also economic aspects. Research period covered 12 months and consumption data obtained from 116 water meters were analysed. Since frequency of the records of these water meters (installed to water supply line and water distribution line) showed difference, water uses in whole facility was evaluated by examining annual total consumptions. Data was presented in Table 4.

\section{Passenger based Water Consumption of the Terminals}

Water is supplied to domestic and international terminals via different lines. However, there was water transfer between terminals (for WC use). Since both terminals are linked, food providing companies in terminals served to whole passengers (domestic and international). Therefore water footprinting of $\mathrm{WC}$ and food service uses has been conducted based on the total water consumption value and also total number of passengers in the airport.

Number of passenger versus water consumption rates (WC use and water consumption of food services in total) was plotted (see figure 1) and the graphic showed that there was a linear correlation between both variables $\left(\mathrm{R}^{2}=0.85\right)$. Monthly change of $\mathrm{L}$ per pax (liter per passenger) values for $\mathrm{WC}$ use and food consumption together are shown in Figure 2. 
Table 3. Monthly terminal passenger capacities and number of flights [12]

\begin{tabular}{|c|c|c|c|c|c|c|}
\hline & \multicolumn{3}{|c|}{ Passenger } & \multicolumn{3}{|c|}{ Aircraft } \\
\hline & Domestic & International & Total & Domestic & International & Total \\
\hline March & 792.962 & 117.422 & 910.384 & 5292 & 996 & 6288 \\
\hline April & 814.659 & 136.144 & 950.803 & 5169 & 1195 & 6364 \\
\hline May & 873.803 & 188.190 & 1.061 .993 & 5510 & 1425 & 6935 \\
\hline June & 813.950 & 192.792 & 1.006 .742 & 5270 & 1593 & 6863 \\
\hline July & 825.257 & 305.005 & 1.130 .262 & 5473 & 2404 & 7877 \\
\hline August & 894.152 & 323.756 & 1.217 .908 & 5492 & 2396 & 7888 \\
\hline September & 827.882 & 260.469 & 1.088 .351 & 5400 & 2023 & 7423 \\
\hline October & 856.320 & 206.113 & 1.062 .433 & 5582 & 1608 & 7190 \\
\hline November & 831.378 & 94.264 & 925.642 & 5382 & 722 & 6104 \\
\hline December & 820.920 & 96.878 & 917.798 & 5488 & 734 & 6222 \\
\hline January & 800.479 & 89.773 & 890.252 & 5218 & 693 & 5911 \\
\hline February & 764.176 & 80.199 & 844.375 & 5087 & 628 & 5715 \\
\hline Total & 9.915 .938 & 2.091 .005 & 12.006 .943 & 64363 & 16417 & 80780 \\
\hline
\end{tabular}

Table 4. Annual water consumtion rates of the water supply and distribution line

\begin{tabular}{|c|c|c|c|c|}
\hline \multicolumn{2}{|c|}{ Water supply line } & \multicolumn{3}{|l|}{ Water distribution line } \\
\hline $\begin{array}{l}\text { Water meters coded as WM } \\
\text { (set on the line from supply } \\
\text { system) }\end{array}$ & $\begin{array}{c}\text { Water } \\
\text { consumption } \\
\mathrm{m}^{3} / \mathrm{yr}\end{array}$ & $\begin{array}{l}\text { Water meters coded as WD (set on the line to end } \\
\text { users) }\end{array}$ & $\begin{array}{c}\text { Water } \\
\text { consumption } \\
\mathrm{m}^{3} / \mathrm{yr}\end{array}$ & $\%$ share \\
\hline WM-1 (from surface water) & 106600 & WD-1 (water to out of terminal area) & 68258 & 0.157 \\
\hline WM-2 (from surface water) & 103770 & WD-2 (water to domestic terminal) & 7005 & 0.016 \\
\hline WM-3 (from ground water & 63295 & WD-3 (water to cooling towers) & 112175 & 0.257 \\
\hline WM-4 (from ground water) & 63728 & WD-4 (water to reservoirs used for WC) & 9150 & 0.021 \\
\hline \multirow[t]{7}{*}{$\begin{array}{l}\text { WM-5-6-7-8 (from ground } \\
\text { water directly to irrigation) }\end{array}$} & 98267 & WD-5 (water to aircraft) & 372 & 0.001 \\
\hline & & WD-6 (water to international terminal offices) & 2006 & 0.005 \\
\hline & & WD-7 ( water to international terminal) & 20530 & 0.047 \\
\hline & & WD-8 (water to Irrigation) & 98267 & 0.226 \\
\hline & & WD-9 ( water to international terminal) & 4417 & 0.010 \\
\hline & & WD-10 (water to domestic terminal) & 84813 & 0.195 \\
\hline & & Unaccounted amount (water to fire control system) & 28667 & 0.066 \\
\hline Total & \multicolumn{3}{|c|}{435660} & \\
\hline
\end{tabular}

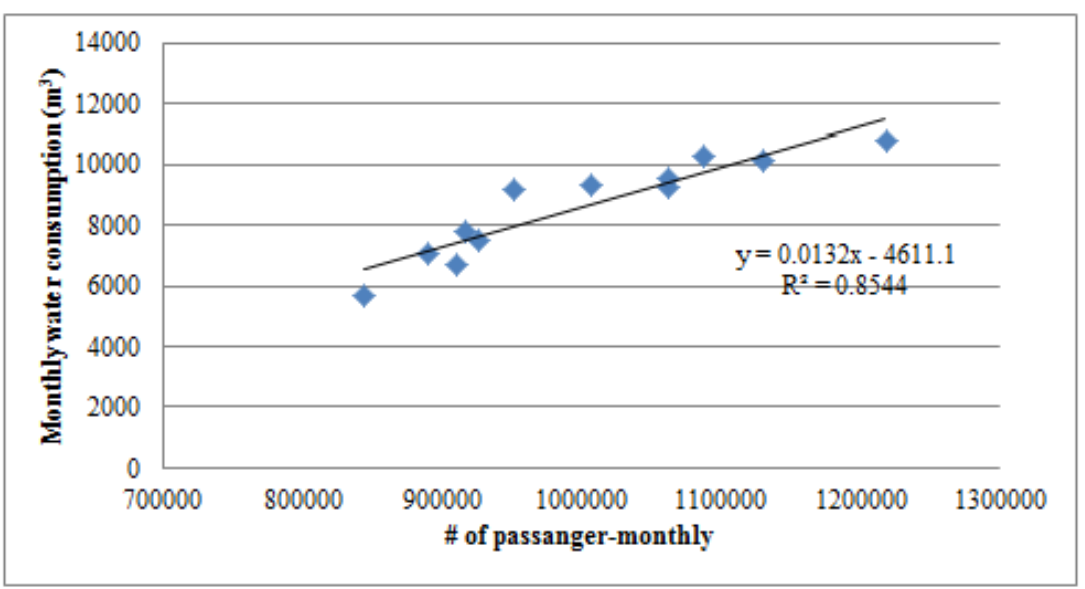

Figure 1. Relationship between number of passangers and water consumption values (WC+Food consumption) 


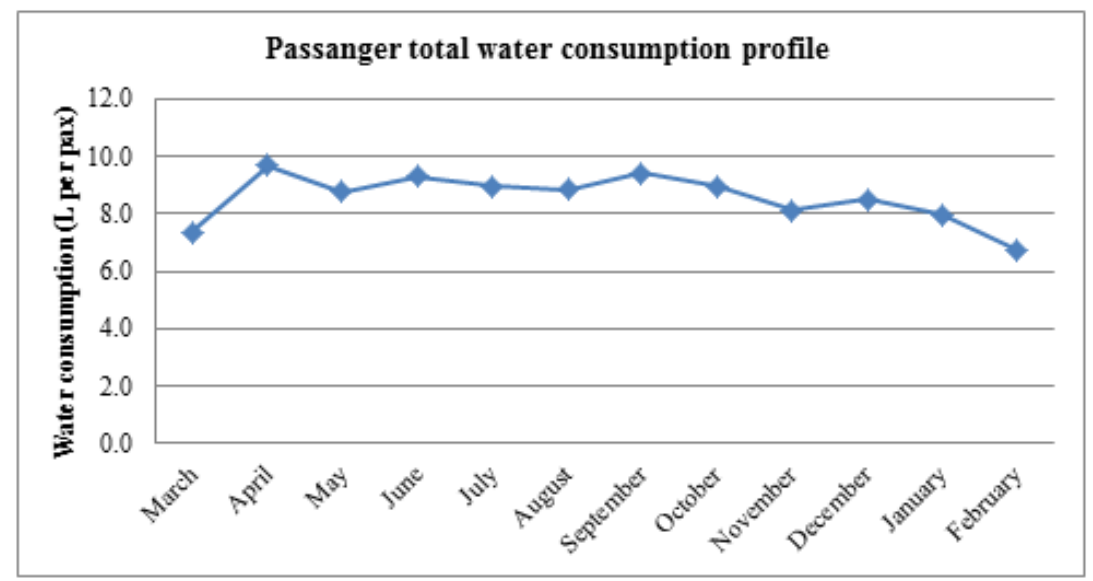

Figure 2. Monthly change of L per pax values

While water used for WC changed between about 6-8.5 L per pax, this value was between 1-1.5 L per pax for food consumption. Therefore passanger based uses was fluctuated between 6.5-10 L per pax in the airport (see Figure 3).

Monthly change in water consumption for WC use and food consumption was quite similar to changes in number of passangers (see Figure 4-5)

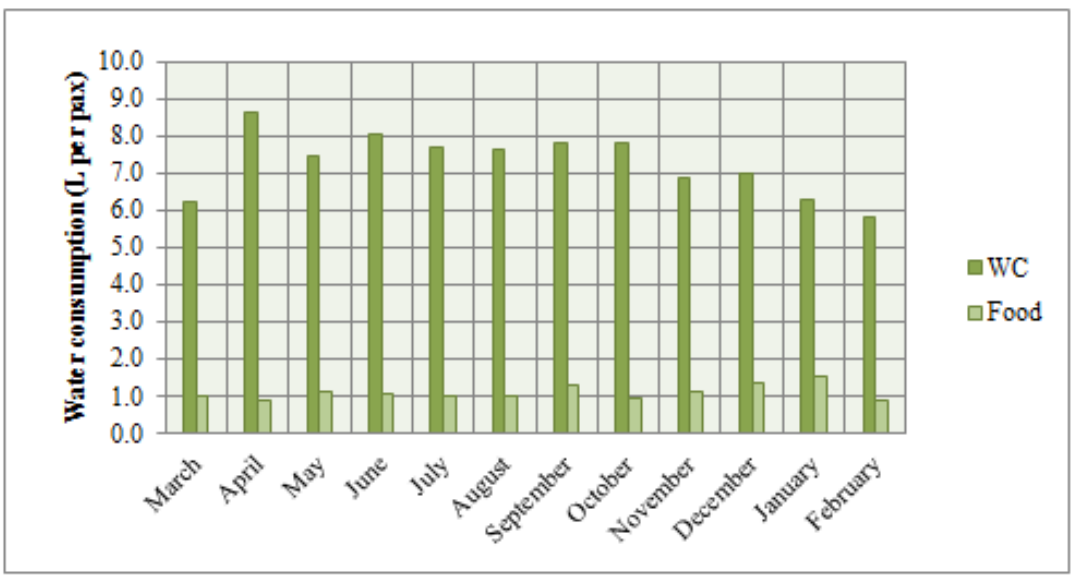

Figure 3. L per pax values for $\mathrm{WC}$ use and food consumption

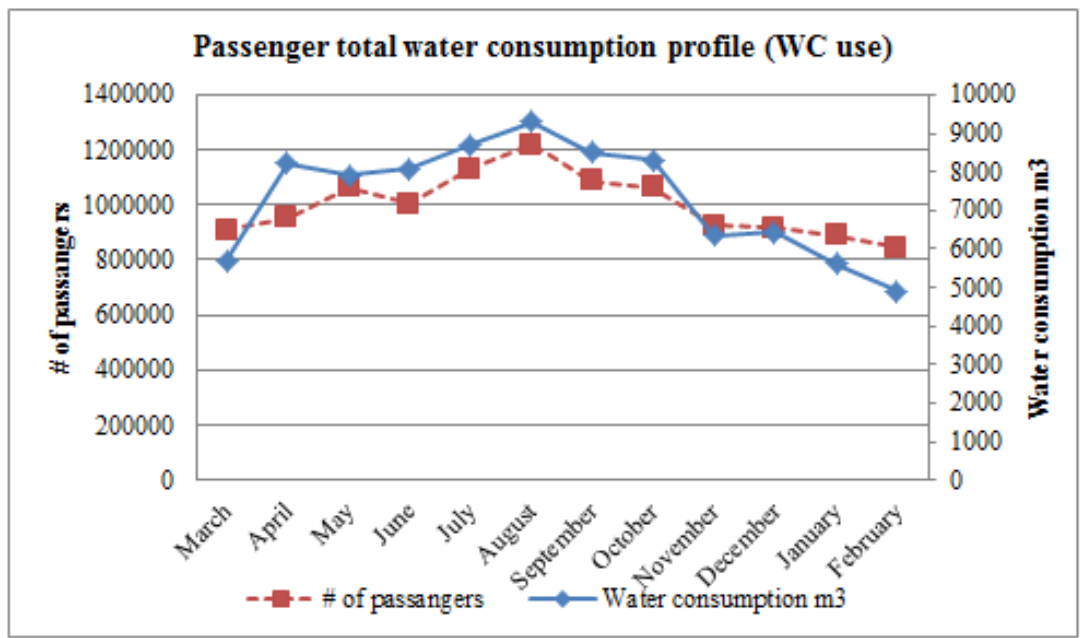

Figure 4. Passanger \& total water consumption profile (WC use) 


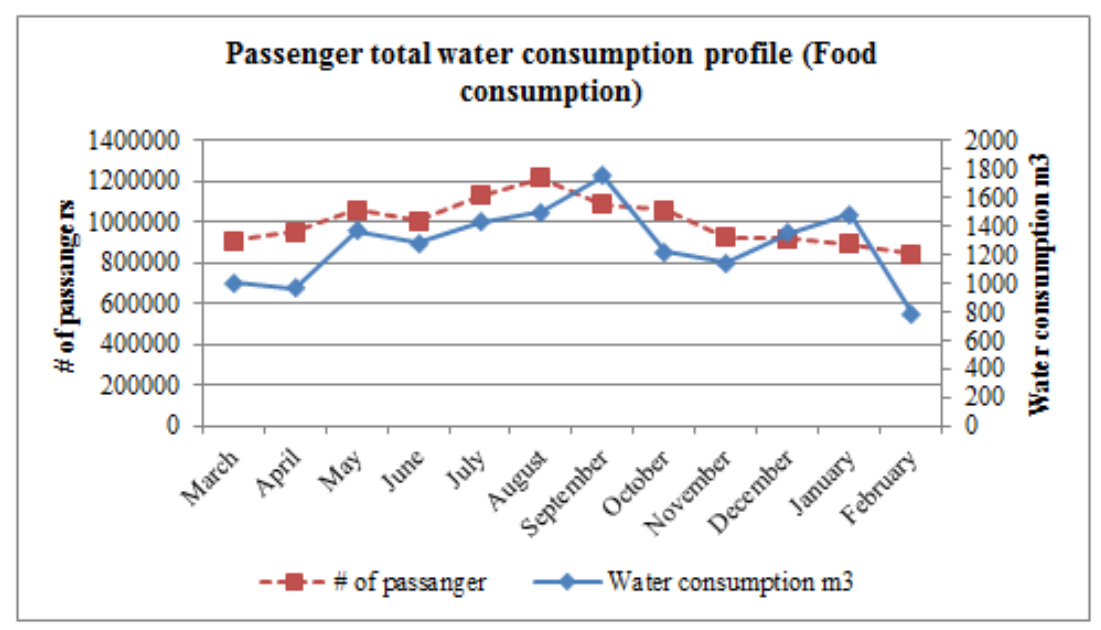

Figure 5. Passenger \& total water consumption profile (Food consumption)

\section{Water Efficiency Plan for the Airport}

Water meter records were evaluated and results showed that within the airport, there were number of particularly high users/activities which are presented in Table 5.

Irrigation, cooling towers and wc use comprised about $76 \%$ of the total use. Therefore priority should be given minimization of the consumption for these activities. These measures and their applicability in terms of economical and physical factors are presented in Table 6 .

Table 5. High water users/activities in the airport

\begin{tabular}{|c|c|c|}
\hline Water users/activities & Annual consumption (m3) & Share in total consumption (\%) \\
\hline Irrigation & 98267 & 0.23 \\
\hline Fire system & 28667 & 0.07 \\
\hline Cooling towers & 112175 & 0.26 \\
\hline Terminal WC use & 87968 & 0.20 \\
\hline
\end{tabular}

Table 6. Water efficiency solutions and their applicability

\begin{tabular}{|c|c|c|c|}
\hline Water users/activities & Water efficiency solutions & $\begin{array}{l}\text { Economical } \\
\text { applicability }\end{array}$ & $\begin{array}{c}\text { Physical } \\
\text { applicability }\end{array}$ \\
\hline \multirow{4}{*}{ Irrigation } & Use of artificial grass & $1 *$ & 5 \\
\hline & Automatic irrigation systems installation (Available) & 3 & 5 \\
\hline & Rainwater harvesting for irrigation & 3 & 2 \\
\hline & Use of sub-surface irrigation (Available) & 3 & 3 \\
\hline $\begin{array}{c}\text { Fire system } \\
\text { (Pressure testing of the fire fighting } \\
\text { system is carried out regularly and } \\
\text { requires potable water. At present } \\
\text { fire testing water is discharged to } \\
\text { stormwater system and not } \\
\text { re-purposed.) }\end{array}$ & $\begin{array}{l}\text { Collection of fire testing water for re-use or re-purposing } \\
\text { for non-potable use is proposed. } \\
\text { (Available) }\end{array}$ & 3 & 3 \\
\hline \multirow{2}{*}{$\begin{array}{c}\text { Cooling towers } \\
\text { (Cooling towers also use high volume } \\
\text { water. Current system recirculates } \\
\text { water for a set number of times and } \\
\text { must then dispose of the water) }\end{array}$} & Changing chillers & 1 & 1 \\
\hline & $\begin{array}{l}\text { Optimising cooling tower makeup water consumption, } \\
\text { convert open loop evaporative humidifiers with closed } \\
\text { loop versions, replace open loop water cooled condensers } \\
\text { by air cooled, or closed-loop water cooled condensers }\end{array}$ & 1 & 1 \\
\hline \multirow{2}{*}{ Terminal WC use } & Increasing rainwater and greywater capacity & 3 & 1 \\
\hline & Replacing restroom fixtures with high-efficiency ones & 2 & 5 \\
\hline \multirow{3}{*}{ General comments } & $\begin{array}{l}\text { Use gray water for landscaping; capture and collect rain } \\
\text { water for non-potable uses }\end{array}$ & 1 & 1 \\
\hline & Training and education of airport staff; & 5 & 3 \\
\hline & Improved water consumption monitoring & 3 & 3 \\
\hline$* 1$ :very low & \begin{tabular}{c|c|c} 
& 3:medium & $4:$ high
\end{tabular} & \multicolumn{2}{|c|}{ 5: very high } \\
\hline
\end{tabular}




\section{Conclusions}

During the research period (from March 2016 to February 2017) the facility served to about 12 million passengers and 81 thousand aircrafts. These passengers and aircrafts are served by various services by airport authorities. These services are linked by water consumption directly or indirectly. Annual water consumption was about $436000 \mathrm{~m}^{3} /$ year in total.

Within the Airport, there were a number of particularly high users/activities:

- $\quad$ Irrigation ( $23 \%$ of the total use)

- $\quad$ Fire control system ( $7 \%$ of the total use)

- Cooling towers ( $26 \%$ of the total use)

- Terminal WC use (20\% of the total use)

While water used for WC changed between about 6-8.5 $\mathrm{L}$ per pax, this value was between 1-1.5 L per pax for food consumption. Therefore passanger based uses was fluctuated between $6.5-10 \mathrm{~L}$ per pax in the airport. This value was below world average rates.

Based on this analysis, the airport authority should consider following projects in near future:

- Use of artificial grass

- Rainwater harvesting for irrigation

- Changing chillers

- Replacing restroom fixtures with high-efficiency fixtures

- Increasing rainwater and greywater capacity (for WC use)

- Revising the operations of cooling towers

- Use gray water for landscaping; capture and collect rain water for non-potable uses

- $\quad$ Training and education of airport staff

- Improved water consumption monitoring

Economical and physical applicability of these methods were also assessed based on judgement of airport technical staff. It was concluded that the most economical measure was "training and education of airport staff" to minimise water consumption. Furthermore physical applicability of "replacing restroom fixtures with high-efficiency ones and use of artificial grass" were relatively higher than the other proposed methods.

\section{Discussion}

Airports are potential environments for implementing programs aiming conserving water due their large consumption, generally for non-potable purposes such as water cooling systems, fire control, cleaning and washing of vehicles, runways and aircrafts and also public uses. The study focused on water consumption footprinting and development of water efficiency plan an airport located in Turkey. Research period covered 12 months and consumption data obtained from 116 water meters were analysed for water footprinting. (WC, food service). Annual water consumption was about $436000 \mathrm{~m}^{3} /$ year in total. Results of the footprinting study showed that irrigation, fire control system, cooling towers and terminal WC uses accounted high use rated with $23 \%, 7 \%, 26 \%$ and $20 \%$. While water used for WC changed between about 6-8.5 L per pax, this value was between 1-1.5 L per pax for food consumption. Based on these results water efficiency plan was developed. In this plan several methods were suggested to minimize water consumption. Among them "training and education of airport staff" was proposed as the most economical solution. Furthermore "improved water consumption monitoring" system could be suggested as applicable method considering economical and physical aspects and should gain priority. Then alternative measures could be chosen based on their economical and physical applicability

\section{REFERENCES}

[1] I.C. Carvalho, M.L Calijuri, P.P. Assemany, M.D.F.M. Silva, R.F.M Neto. A.F. Santiago, M.H.B. Souza. Sustainable airport environments: a review of water conservation practices in airports. Resour. Conserv. Recy. 74, 27-36, 2013.

[2] R.A. Crop, M.L. Young, J Joley and W. Dawis. Water efficiency management strategies for airports. The National Academies Press, 2016.

[3] L. Hack, D. Barnes. Auckland International Airport water efficiency plan update. SLR Consulting NZ. (2016)

[4] ACRP- Airport Cooperative Research Program Interpreting the Results of Airport Water Monitoring. Research Report 166. The National Academies Press, 2017.

[5] Bristol airport. 2014 Operations monitoring report, 2015.

[6] Schiphol Group. Facts \& 2013 Figures, 2014.

[7] Gatwick Airport London-GAL. 2016 Performance Report; Gatwich Airport; 10 Decade of Change, 2017.

[8] Fraport. Abridged environmental statement 2016, 2017.

[9] LHR. Sustainability 2016 performance report Heathrow Airport, 2017.

[10] AENA. Madrid Barajas Airport 2010 Environmental Management Report; Aena's Commitment, 2010.

[11] C. Hitz. Water conservation at Vancouver International Airport strategies for water conservation and efficiency. Report prepared at the request of Vancouver Airport Authority, in partial fulfillment of GEOG419: Research in Environmental Geography. University of British Columbia, 2015.

[12] SWA-State Water Authoriry-DHMI. Annual reports on airports in Turkey, 2018. 